\title{
GSM based Android Application: Appliances Automation and Security Control System using Arduino
}

\author{
Kainat Fareed Memon, Javed Ahmed Mahar, Hidayatullah Shaikh, Hafiz Ahmed Ali, Farhan Ali Surahio \\ Department of Computer Science, Shah Abdul Latif University, Khairpur Mir's, Sindh, Pakistan
}

\begin{abstract}
Now-a-days, automation is playing significant role using android phone in human life, particularly, handicapped and senior citizens. Appliances automation allows users to control different appliances such as light, fan, fridge and AC. It also provides security system like door controlling, temperature \& fire detection and water shower. Furthermore, security cameras are used to control and monitored by the users to observe activity around a house. It has been observed that the internet services in interior Sindh are not as much better as required. Hence, GSM SIM900A based android application is developed named Appliances Automation \& Security Control System using Arduino. The developed system is decomposed into two separate entities: (1) hardware is designed and developed using Arduino (MEGA 2560) with other required electronics components which is programmed using embedded $C$ language, (2) an Android app which provides freedom to user to control and access the electronic appliances and the security system without internet. The developed application is tested in Karachi, Sukkur and Khairpur with ZONG, Moblink, Telenor and Ufone. The acceptable results are achieved at Karachi and Sukkur but suitable results are not calculated at Khairpur in terms of delay due to the frequency of selected GSM Module.
\end{abstract}

Keywords-android application; gsm module; security system; Arduino

\section{INTRODUCTION}

The basic idea of home automation is observed since 1970 s but expectations of the peoples are continuously and constantly increase due to the advancement of the technology and internet services. During the literature review, it has been observed that different researchers proposed architectures for various efficient and convenient home automation systems. Even the technology is entirely changed but the function and importance of home automation systems are same as previous [1] [2].

Recently, life is increasingly tight with the rapid growth in communications and information technology. The electronic and electrical environment with respect to automation of the household activities including centralized control of appliances, and other systems, to provide improved convenience, comfort, energy efficiency and security [3]. Appliances automation for the elderly and disabled can provide increased quality of life for persons who might otherwise require caregivers or institutional care. It can also provide remotely accessible environment in which each appliance can be remotely accessed and controlled using software as an interface, which includes an Android application [4].

The intellectual societies bring information where safe, economic, comfortable and convenient life has become the ideal for every modern family. In Pakistan, most of the people use Android phones for improving the living style but overall environment is not secure and safe. Therefore, it is a great need of automation systems. The GSM based android software application along with the security system is developed and presented in this paper. The developed application is useful enough for users including handicapped persons.

\section{LITERATURE REVIEW}

Many research contributions have been published pertaining to the home automation and automatic security systems. The fundamental information regarding the home automation and security systems implemented with Arduino and GSM technology are described and presented by Kaur [5]. Some researchers used Bluetooth technology in networking environment as well as automation systems for instance; Sriskanthan [6] developed an application for home automation using Bluetooth technology.

In previous past, home automation systems are ambiguous and complicated due to the system hardware but nowadays these systems are used by many people across the world with modern technologies. Touch screen based home automation system is developed by Wagh [7] using GSM and Zig-Bee. The GSM technology is also used by Singh [8] in the developed appliance system. The android application having low cost and provide switching services is presented and with object oriented programming language by Pawar [9]. The Internet of Things was used in the proposed system for controlling and monitoring the various appliances. GSM is widely used in such kind of application that controls the appliances. In Pakistan most of the offices, business platforms and educational institutes have not any appliances security system that provide facility to control the devices through-out the smart phone applications. Thus, no work has been found in Pakistan from the side of security control system.

The security of homes is mandatory in countries like Pakistan. The survey was conducted by Chitnis [10] from the peoples having different background for the awareness of the automatic home automation system and its significance particularly in terms of security. The home security system is developed and presented by Mali [11] using motion sensor 
and PIR sensor. It is noted that Arduino board and GSM is used for data processing and messaging. Moreover, low power Bluetooth protocol is used in automation system by Chandra [12] with suitable authentication for correct person. On the other hand, PIC based remote control system is presented by Erol [13] for intelligent homes. This system is electrically and optically isolated system that is much secure. The Pin-Check algorithm is used in developed system in order to enhance and improve the security.

\section{SySTEM DESIGN AND EXECUTION PROCESS}

The core purpose of this project is to develop software application for home automation and security control system using different hardware components. Various GSM Modules having different frequencies are available as shown in "Fig. 1" but GSM SIM900A Module is selected in this project. This Module is used because of the availability, coverage and security and it is widely used for establishing the connections where Internet access is not possible. The server uses AT commands to communicate with the GSM modem [4] for controlling the SMS and send it to the Arduino for further process.

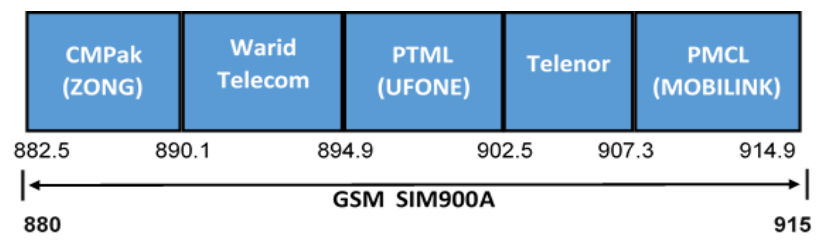

Fig. 1. GSM Module Frequencies

During the literature review, it has been found that Arduino board is used as the controller to interface the appliances [3]. When the embedded systems start, user first receives a message that the system is ready for process. It uses certain peripheral drivers and relays for successful communication and controlling the load of appliances. The touch screen smart phone is used to handle the application using the GUI. The developed application automatically generates SMS messages based on the user commands and sends it to the GSM modem attached to the Arduino. This allows the user to control the selected home appliances as well as security system. The complete system architecture of the developed software project is depicted in "Fig. 2".

Furthermore, for understanding and easy accessing there is a GUI for controlling the different devices such as bulb saver, fan etc. The list of various functions is available in the core screen of the application. The user can select any function among the available list for controlling the device. After that user can see the action performed on the selected device. Now if user wants to enable or disable the particular device of the appliances then application give a facility to do as per the requirement and wish of the user. Now the function of GSM is begins, the GSM module decodes the received messages via SMS and performs the given commands. It is noted here that, the SMS depends on the used networks and there is a possibility of late delivery of the message due to the availability of the signals. The flow chart of the complete execution process of developed software application is shown in "Fig 3". The flow chart is taken from [14] except the LAN because GSM is used in this project.

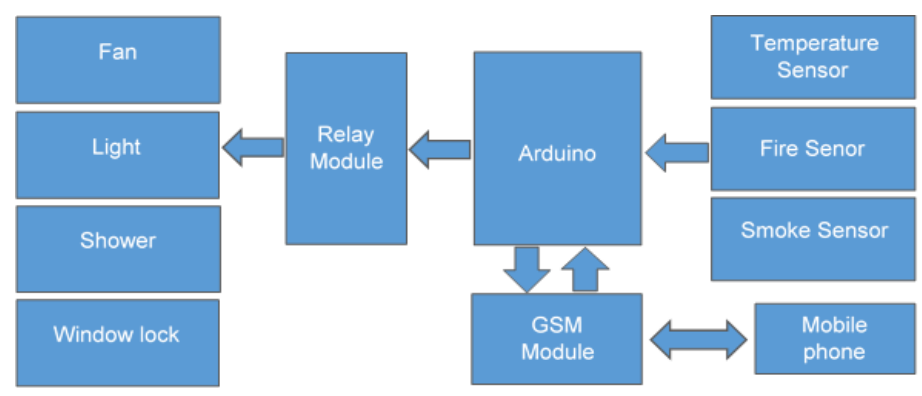

Fig. 2. System Architecture of Developed Software Application

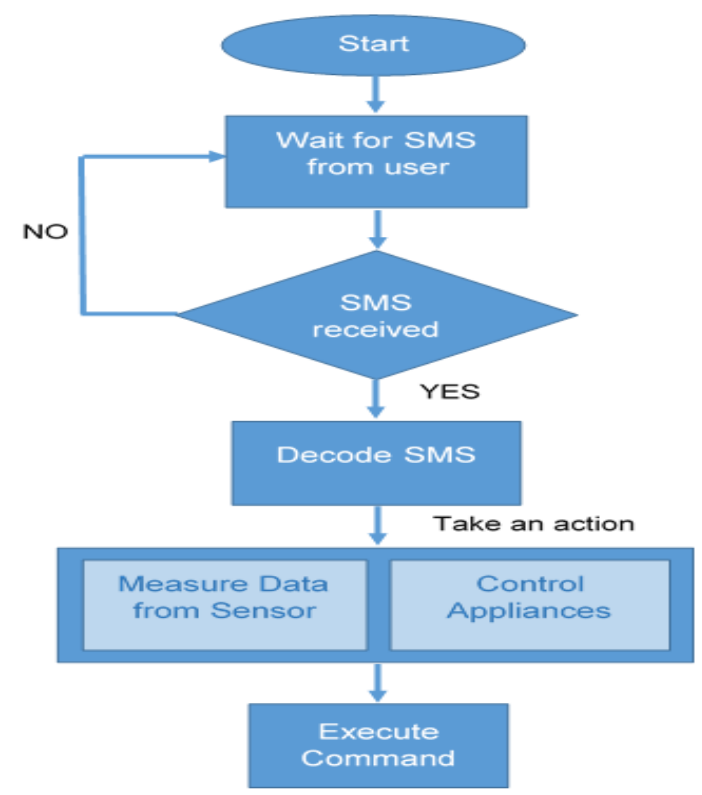

Fig. 3. Execution Process of Developed Software Application

The developed application consists of four components: Light controlling, Door controlling, Fire \& Smoke detection and Temperature sensing. The application has ability to automatically activate the alarm when system detects any symptom of smoke, gas or fire. If fire detected then the water shower is activated. Noted that, if user is not present in his home then he can watch the live streaming through Internet. One of the ability of the developed application, user can control multiple appliances concurrently because the system is able to verify the status of the appliances simultaneously. For this process, security camera is connected to the internet and sending live video streaming to a domain like YouTube. Mobile phone facilitates to watch that streaming which is available on to the domain with corresponding URL. The accessing process of security camera is depicted in "Fig.4". 


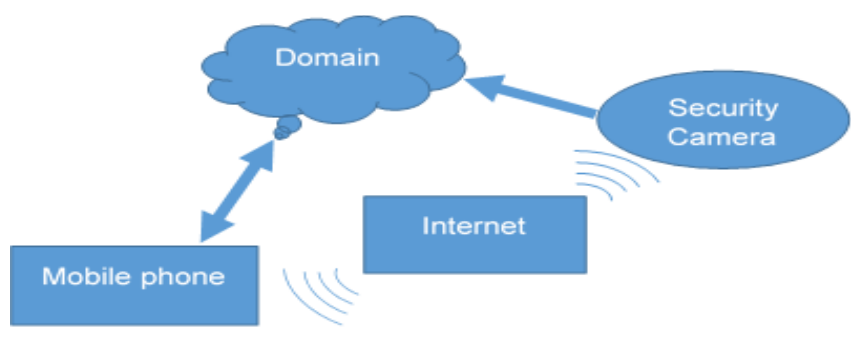

Fig. 4. Accessing Process of Security Camera

\section{RESULTS AND DISCUSSION}

The developed software application with complete automation system is individually tested in three different cities of province Sindh. The selected cities are Karachi, Sukkur and Khairpur, these cities are selected due to the performance evaluation of developed application and concerned hardware. For the analysis and further comparison, five telecommunication companies i.e. ZONG, Warid, Ufone, Telonor and Moblink are selected which are less or more works on these selected cities. Moreover, three different places are selected in each city for testing the frequency of the GSM Module. The aim of this analysis and comparison is to explore the availability of the signals with certain ranges and the performance of the developed software application.

\section{A. Karachi}

The developed system is practically tested in three different areas of Karachi i.e. Gulshan-e-Iqba, Cant Station and Ghulistan -e- Johar. It is noted that developed system is tested in ten different locations of each area of Karachi city and calculated the performance in percentage in terms of the availability of the signals and functionality of the application. The average performance accuracy with ZONG is calculated $55 \%$, in selected three areas $81.6 \%$ is calculated with Ufone, $65 \%$ and $70 \%$ is achieved with Telenor and Moblink respectively. The detailed calculated results of developed application at Karachi are shown in Table I and calculated results are graphical represented in "Fig.5" for analysis and comparison.

The calculated results proved that Ufone is better than the other telecommunication networks because $81.6 \%$ performance is achieved with this network. On the other, inferior results are received with ZONG. The results of Telenor and Moblink are also at acceptable level.
TABLE I. CALCULATED RESUlTS OF DEVELOPED APPLICATION AT KARACHI

\begin{tabular}{|c|c|c|c|c|}
\hline \multicolumn{5}{|l|}{ City: Karachi } \\
\hline \multirow[b]{2}{*}{ Selected Network } & \multicolumn{3}{|c|}{ Selected Areas } & \multirow[b]{2}{*}{$\begin{array}{l}\text { Mean } \\
(\%)\end{array}$} \\
\hline & $\begin{array}{l}\text { Gulshan - } \\
\text { e-Iqbal } \\
(\%)\end{array}$ & $\begin{array}{l}\text { Cant } \\
\text { Station } \\
(\%)\end{array}$ & $\begin{array}{l}\text { Gulistan } \\
\text { e Johar } \\
(\%)\end{array}$ & \\
\hline $\begin{array}{l}\text { ZONG } \\
(882.5-890.1 \\
\text { MHz) }\end{array}$ & 40 & 65 & 60 & 55 \\
\hline $\begin{array}{l}\text { Ufone } \\
\text { (894.9 - } 902.5 \\
\text { MHz) } \\
\end{array}$ & 70 & 85 & 90 & 81.6 \\
\hline $\begin{array}{l}\text { Telenor } \\
(902.5-907.3 \\
\text { MHz) }\end{array}$ & 50 & 80 & 65 & 65 \\
\hline $\begin{array}{l}\text { Moblink } \\
\text { (907.3 - 914.9 } \\
\text { MHz) }\end{array}$ & 55 & 70 & 85 & 70 \\
\hline
\end{tabular}

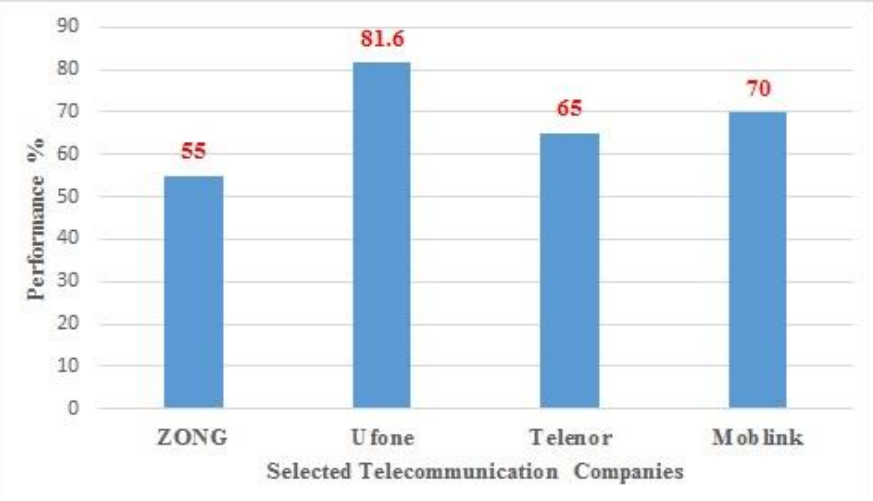

Fig. 5. Calculated Performance with Telecommunication Companies at Karachi

\section{B. Sukkur}

For testing the developed software project at Sukkur, three areas such as Airport Road, Race Course Road and Old Sukkur. Ten different locations of Sukkur were selected for evaluating the performance of selected telecommunication networks using our developed project. We have achieved the better accuracy after testing the proposed system. Thus, the average performance accuracy with ZONG is calculated $90.6 \%$. The performance accuracy of $81.6 \%$ is calculated with Ufone, $76 \%$ is achieved with Telenor and $85 \%$ is achieved 
with Moblink. The statistics of calculated results at Sukkur city is given in Table II and calculated results are graphical represented in "Fig.6" for analysis and comparison.

TABLE II. CAlCulated RESUlts OF DEVEloped APPLICATION AT SUKKUR

\begin{tabular}{|c|c|c|c|c|}
\hline \multicolumn{5}{|l|}{ City: Sukkur } \\
\hline \multirow[b]{2}{*}{ Selected Network } & \multicolumn{3}{|c|}{ Selected Areas } & \multirow[b]{2}{*}{$\begin{array}{l}\text { Mean } \\
(\%)\end{array}$} \\
\hline & $\begin{array}{l}\text { Airport } \\
\text { Road }(\%)\end{array}$ & $\begin{array}{l}\text { Race } \\
\text { Course } \\
\text { Road }(\%) \\
\end{array}$ & $\begin{array}{l}\text { Old } \\
\text { Sukkur } \\
(\%) \\
\end{array}$ & \\
\hline $\begin{array}{l}\text { ZONG } \\
(882.5-890.1 \\
\text { MHz) }\end{array}$ & 90 & 95 & 87 & 90.6 \\
\hline $\begin{array}{l}\text { Ufone } \\
\text { (894.9 - } 902.5 \\
\text { MHz) }\end{array}$ & 70 & 85 & 90 & 81.6 \\
\hline $\begin{array}{l}\text { Telenor } \\
(902.5-907.3 \\
\text { MHz) } \\
\end{array}$ & 75 & 80 & 73 & 76 \\
\hline $\begin{array}{l}\text { Moblink } \\
(907.3 \text { - } 914.9 \\
\text { MHz) }\end{array}$ & 85 & 90 & 80 & 85 \\
\hline
\end{tabular}

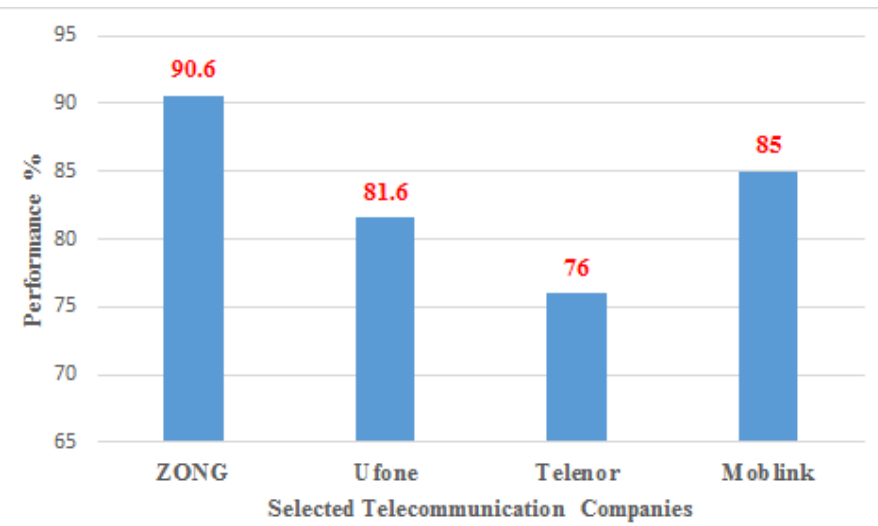

Fig. 6. Calculated Performance with Telecommunication Companies at Sukkur

As fig.6 shows that ZONG is more suitable communication network at Sukkur because high performance is calculated with this network which is $90.6 \%$. With small variations, other three networks are also performed well. However, poor results are achieved with Telenor which is $76 \%$.

\section{Khairpur}

The developed software application is also tested in various locations of Khairpur. For this, three areas of Khairpur i.e. SALU Khairpur, Station Road and Jillani Muhalla are selected. The performance of the system is calculated using the formula of mean. The performance accuracy with ZONG is calculated $45 \%$, in selected three areas $75.3 \%$ is calculated with Ufone, $68 \%$ is calculated with Telenor and $71.6 \%$ is calculated with Moblink. The statistical information of calculated results is shown in Table III and calculated results are also graphical represented in "Fig.7" for comparison.
TABLE III. CALCULATED RESUlTS OF DEVELOPED APPLICATION AT KHAIRPUR

\begin{tabular}{|c|c|c|c|c|}
\hline \multicolumn{5}{|l|}{ City: Khairpur } \\
\hline \multirow[b]{2}{*}{ Selected Network } & \multicolumn{3}{|c|}{ Selected Areas } & \multirow[b]{2}{*}{$\begin{array}{l}\text { Mean } \\
(\%)\end{array}$} \\
\hline & $\begin{array}{l}\text { SALU } \\
\text { Khairpur } \\
(\%)\end{array}$ & $\begin{array}{l}\text { Station } \\
\operatorname{Road}(\%)\end{array}$ & $\begin{array}{l}\text { Jillani } \\
\text { Muhala(\%) }\end{array}$ & \\
\hline $\begin{array}{l}\text { ZONG } \\
(882.5-890.1 \\
\text { MHz) }\end{array}$ & 30 & 45 & 60 & 45 \\
\hline $\begin{array}{l}\text { Ufone } \\
(894.9 \text { - } 902.5 \\
\text { MHz) }\end{array}$ & 55 & 84 & 87 & 75.3 \\
\hline $\begin{array}{l}\text { Telenor } \\
(902.5-907.3 \\
\text { MHz) }\end{array}$ & 64 & 67 & 73 & 68 \\
\hline $\begin{array}{l}\text { Moblink } \\
(907.3 \text { - } 914.9 \\
\text { MHz) }\end{array}$ & 75 & 72 & 68 & 71.6 \\
\hline
\end{tabular}

On the basis of received results, it is concluded that Ufone telecommunication network is more suitable than others because $75.3 \%$ performance is achieved with this network. The lesser results are received with ZONG. The results of Telenor and Moblink are also at acceptable level.

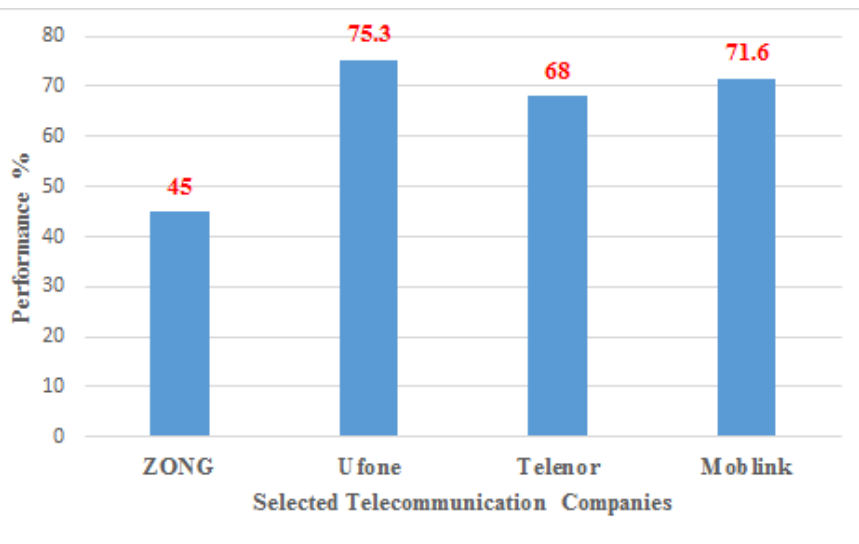

Fig. 7. Calculated Performance with Telecommunication Companies at Khairpur

\section{CONCLUSION}

The automation applications permit people to control the appliances used in their homes, offices, hospitals etc. It provides security system with cameras for controlling and monitoring activities around the home. This paper presented the system architecture and the calculated results which are testing at different areas and locations of Karachi, Sukkur and Khairpur with different telecommunication networks used in Pakistan. Authors calculated performance of $81.6 \%$ in Karachi using Ufone, $90.6 \%$ is calculated with ZONG at Sukkur and $75.3 \%$ is received with Ufone at Khairpur. On the basis of calculated results, it is proved that Ufone is better than the other selected telecommunication networks. The outcome of this study will be helpful for the students as well as researchers who want to put their efforts towards the designing and development of automation \& security systems. The future scope of proposed system will led to implement rigid security for schools and other educational environment. 


\section{REFERENCES}

[1] C. A. Jose, R. Malekian, "Smart home automation security: A literature review", Smart Computing Review, Vol. 5, No. 4, Pp. 269-285, 2015.

[2] S. B. Priya, R. Geethamani, "Design and implementation of home automation using power electronic switches", International Journal of Advanced Information and Communication Technology, Vol. 2, Issue 12, Pp. 1127-1129, 2016.

[3] D. Javale, M. Mohsin, S. Nandanwar, M. Shingate, "Home automation and security system using android adk", International Journal of Electronics Communication and Computer Technology, Vol. 3, Issue 2, Pp. 382-385, 2013.

[4] S. Palaniappan, N. Hariharan, T. N. Kesh, S. Vidhyalakshmi, Angel, S. Deborah, "Home automation system- A study", International Journal of Computer Applications, Vol.116, No. 11, Pp. 11-18, 2015.

[5] S. Kaur, R. Singh, N. Khairwal, P. Jain, "Home automation and security system", Advanced Computational Intelligence: An International Journal, Vol. 3, No. 3, Pp. 17-23, 2016.

[6] N. Sriskanthan, A. Tan, A. Karande, "Bluetooth based home automation system", Microprocessors and Microsystems, Vol. 26, Pp. 281-289, 2002.

[7] M. Wagh, V. Gadhari, H. Sonawane, S. Shelar, R. Mahale, "Touch screen based home automation system", International Research Journal of Engineering and Technology, Vol. 3, Issue 3, Pp.1530-1531, 2016.
[8] P. Singh, K. Chotalia, S. Pingale, S. Kadam, "A review paper on smart gsm based home automation system", International Research Journal of Engineering and Technology, Vol. 3 Issue 4, Pp.1838-1843, 2016.

[9] N. P. Pawar, S. Ramachandran, P. N. Singh, V. V. Wagh, "A survey on internet of things based home automation system", International Journal of Innovative Research in Computer and Communication Engineering, Vol. 4, Issue 1, Pp. 76-81, 2016.

[10] S. Chitnis, N. Deshpande, A. Shaligram, "An investigative study for smart home security: Issues, challenges and countermeasures", Wireless Sensor Network, Vol. 8, Pp. 61-68, 2016.

[11] V. Mali, A. Gorasia, M. Patil, P. S. Wawage, "Home automation and security using arduino microcontroller", International Journal of Research in Advent Technology, Special Issue National Conference, Pp. 214-217, 2016.

[12] G. P. Chandra, S. Venkateswarao, "Ad-Hoc low powered 802.15.1 protocol based automation system for residence using mobile devices", International Journal of Computer Science \& Technology, Vol. 2, No. 1, Pp. 93-96, 2011.

[13] Y. Erol, H. Balik, S. Inal, D. Karabulut, "Safe and secure pic based remote control application for intelligent home", International Journal of Computer Science and Network Security, Vol.7, No.5, Pp. 179-182, 2007.

[14] P. P. Kumar, T. G. Vasu, "Home automation \& security system using arduino android adk", International Journal of Emerging Trends in Engineering Research, Vol. 3, No. 6, Pp. 190-194, 2015. 